Tropical Journal of Pharmaceutical Research October 2017; 16 (10): 2373-2378

ISSN: $1596-5996$ (print); 1596-9827 (electronic)

(C) Pharmacotherapy Group, Faculty of Pharmacy, University of Benin, Benin City, 300001 Nigeria.

All rights reserved.

Available online at http://www.tjpr.org

Original Research Article

http://dx.doi.org/10.4314/tjpr.v16i10.9

\title{
Anti-trypanosomal effect of Malva sylvestris (Malvaceae) extract on a Trypanosoma brucei brucei-infected mouse model of sleeping sickness
}

\author{
Yan-Bing Ding ${ }^{1}$, Jun Chen ${ }^{1}$, Li-Xia Huang ${ }^{2}$, Ye-Li Gong ${ }^{2}$, Fa-Hu Yuan ${ }^{2}$ and Jin- \\ Wen $\mathrm{Tu}^{1 *}$ \\ ${ }^{1}$ Department of Neurology, Hubei Provincial Hospital of Traditional Chinese Medicine, WuHan, HuBei Province 430061, ${ }^{2}$ School \\ of Medicine, Jianghan University, WuHan, HuBei Province 430056, China
}

*For correspondence: Email: hlxgw2011@163.com; Tel/Fax: 0086-27-88929147

\begin{abstract}
Purpose: To evaluate the antitrypanosomal activity of Malva sylvestris (MS) extract in a Trypanosoma brucei brucei-infected mouse model of sleeping sickness.

Methods: Sleeping sickness was induced by the intraperitoneal injection of Trypanosoma brucei bruceiinfected blood in mice. Confirmation of parasitaemia was performed by estimating the parasite count in the plasma on the 12th day after inoculation. All the mice were divided into five groups: control group that received neither infection nor treatment; negative control that was infected with the parasite but did not receive treatment; MS-treated group that receive MS extract (250 and $500 \mathrm{mg} / \mathrm{kg}$, ip) and standard (STD) group that received levamisole ( $7.5 \mathrm{mg} / \mathrm{kg}$, ip) for 7 days after the development of parasitaemia. A further parasite count was performed in the blood and cerebrospinal fluid (CSF) after the treatment period. Humoral antibody response, delayed hypersensitivity reaction, and mobilization of leucocytes were determined after the treatment period in SRBC-sensitized mice.

Results: The results indicate that treatment with MS significantly decreased body weight and parasite count in the blood and CSF of mice with Trypanosoma brucei brucei-induced sleeping sickness compared with that in the negative control group. There was a significant increase in paw swelling and decrease in secondary antibody in the MS-treated group compared with that in the negative control group. However, treatment with MS extract also enhanced the mobilization of the total leucocyte count compared with that in the negative control group.

Conclusion: The results demonstrate the anti-trypanosomal activity of Malva sylvestris extract via immunomodulation in a Trypanosoma brucei brucei-infected mouse model of sleeping sickness.
\end{abstract}

Keywords: Malva sylvestris, Trypanosoma brucei brucei, Sleeping sickness, Immunomodulatory activity, Delayed hypersensitivity reaction

Tropical Journal of Pharmaceutical Research is indexed by Science Citation Index (SciSearch), Scopus, International Pharmaceutical Abstract, Chemical Abstracts, Embase, Index Copernicus, EBSCO, African Index Medicus, JournalSeek, Journal Citation Reports/Science Edition, Directory of Open Access Journals (DOAJ), African Journal Online, Bioline International, Open-J-Gate and Pharmacy Abstracts

\section{INTRODUCTION}

Sleeping sickness is a disease that occurs because of infection by protozoa (genus: Trypanosoma) and is commonly known as epidemic encephalitis or human African trypanosomiasis [1]. A report of $\mathrm{WHO}$ has revealed that approximately 60 million people of African countries are at a risk to become infected with sleeping sickness, which is found to be fatal if left untreated [2]. The literature suggests that sleeping sickness is transmitted through the tsetse fly and is commonly known as Trypanosoma brucei brucei [3]. This disease 
occurs in two stages. Stage 1 is commonly known as hemolymphatic stage 1in which the parasite attacks the peripheral organs and proliferate in the lymph and blood. Stage 2 is called meningoencephalitic stage 2 in which the infection reaches the CNS by crossing the blood brain barrier [4,5]. In the second stage, the disease affects the neurological functions, including sleeping, and it causes mortality if it remains untreated. Disease caused due to microbial agent fundamentally protected by immune system. Activation of the immune system stimulates the release of mediators of inflammation such as chemokines and cytokines, thereby managing the disease [6].

However, in this modern era of medicine, it remains challenging to treat such a condition. Treatment of this disease requires the administration of a parental preparation for a longer duration with less efficacy, and, most of the time, it is not affordable for patients. Thus, an alternative therapy is required to manage this disease. Malva sylvestris L. (Malvacea) is traditionally used as medicine in China [7]. MS was reported to possess anti-inflammatory, antioxidant, bacteriostatic, antinociceptive and anticholinesterase activity [8,9]. Phytochemical investigation revealed that $\mathrm{MS}$ herbs contain several biologically active chemical components such as essential oils, sesquiterpenes, leucoanthocyanidines, anthocyanidines, coumarins and anthocyanins [10]. Coumarins and anthocyanins were reported to protect neurodegeneration in cerebral ischaemia [11]. Thus, we assessed the antitrypanosomal effects of Malva sylvestris extract on a Trypanosoma brucei brucei-infected mouse model.

\section{EXPERIMENTAL}

\section{Animal}

Male albino mice of 25 to $50 \mathrm{~g}$ body weight were used in the given investigation. All the mice were housed under a controlled condition specified as per the guidelines. All the experiments used in the given study are approved by institutional animal ethical committee of Hubei Provincial Hospital of TCM, China (no. HPH/IAEC/2016/02) and the study followed the guidelines of Association for the Assessment and Accreditation of Laboratory Animal Care International (AAALAC) for experimentation and animal use [12].

\section{Preparation of extract}

The whole plant of Malva sylvestris was collected and authenticated from Dr. Wu Wang of
Jianghan University, China. The complete plant was air dried after washing it. The dried plants were cut into small pieces and later ground into a coarse powder using a grinder. This powder was kept in $95 \%$ methanol in a bottle for 7 days for the maceration. The extract was filtered, and the filtrate was dried using a rotary evaporator. The yield of the extract was found to be $16.5 \% \mathrm{w} / \mathrm{w}$.

\section{Trypanosome parasite}

The Trypanosome strain (Trypanosoma brucei brucel) was procured from the School of Medicine, Jianghan University, China. It was maintained at the department by serial passage in the animals. However, the identification of Trypanosoma brucei brucei was performed by observing the morphology of the parasite.

\section{Experimentation}

All the mice were separated into five different groups such as the control group that received neither infection nor treatment, a negative control group that was infected with the parasite but did not receive treatment, an MS-treated group that received the MS extract (250 and $500 \mathrm{mg} / \mathrm{kg}$, ip) and a STD group that received levamisole (7.5 $\mathrm{mg} / \mathrm{kg}$, ip) for 7 days after the development of parasitaemia.

Infected mice were used to collect the blood by cardiac puncture, followed by dilution in saline solution. This blood was then inoculated into all the groups of mice by ip injection containing approximately $1 \times 10^{6}$ Trypanosome cells $/ \mathrm{ml}$. All the mice were kept for 12 days for the development of parasitaemia. All the animals were treated with the MS extract for 7 days, and microscopic examination was performed at an interval of every 2 days for the estimation of parasitaemia.

\section{Determination of the body weight and parasite count}

The body weight and parasite count in the blood of all the infected mice were estimated on every alternate day after the inoculation of the parasite. However, the parasite count was estimated in the CSF at 0 and 7 days of infection. The animals were anesthetized by the injection of chloral hydrate $(400 \mathrm{mg} / \mathrm{kg})$, and the CSF was collected by making a puncture at the cisterna magna using a stereotaxic frame. The CSF was collected by inserting syringes in it. The parasite counting was performed using a microscope as described previously. 


\section{Preparation of sheep red blood cells (SRBCs)}

In this study, blood collected from sheep (SRBCs) was used as an antigen. Red blood cells were separated from the collected blood, followed by washing with phosphate-buffered saline $(\mathrm{pH} 7.2)$ three times by centrifugation at $2000 \times$ for $10 \mathrm{~min}$. After washing, the SRBCs obtained were subjected to serological tests using a $2 \%$ suspension of SRBCs in PBS and prepared for immunization using a $10 \%$ suspension of the cells.

\section{Delayed hypersensitivity reaction test}

SRBC was used to induce delayed hypersensitivity reaction in the mice. Thirty mice were separated into five different groups as described in the above section of the study. On day 0 , infected mouse SRBCs $\left(0.2 \mathrm{~mL}, 1 \times 10^{9}\right)$ was injected into the planter region of the right hind foot pad for sensitization. However, in the left hind pad, another injection of SRBCs was administered subcutaneously on day six. However, the thickness of left foot pad was estimated by a vernier calliper before and after $24 \mathrm{~h}$ of the challenge.

\section{Humoral antibody response}

Blood was withdrawn from all the animals and was centrifuged at 10,000 rpm. Hemagglutination technique was used for the estimation of the antibody titre. In a micro titre 96-well plate, serum was diluted using normal saline up to two folds; later, $1 \%$ of SRBCs was added to each dilution. Thereafter, the plates were incubated for $60 \mathrm{~min}$ at $37{ }^{\circ} \mathrm{C}$, and then it was observed for hemagglutination.

\section{Evaluation of the mobilization of leucocytes}

The method reported by Ribeiro et al was used to estimate the mobilization of leucocytes in this study. At the end of the treatment period, all the animals were sacrificed $4 \mathrm{~h}$ after the ip injection of $0.5 \mathrm{~mL}$ of agar solution. The peritoneal region of all the mice was washed with phosphate buffer solution containing $10 \%$ EDTA $(0.5 \mathrm{~mL})$. Next, a haemocytometer was used to estimate the total leucocyte count in the peritoneal fluid, and a Giemsa-stained perfusate smear was observed microscopically for the estimation of the differential cell count.

\section{Statistical analysis}

All the data were represented as means \pm standard deviation $(n=10)$. All the results were analysed statistically by one-way analysis of variance and Dunnett's post-hoc test (GraphPad Prism 6.1., La Jolla, CA, USA). $P<0.05$ was considered statistically significant.

\section{RESULTS}

\section{Effect of Malva sylvestris extract on body weight}

Effect of Malva sylvestris extract on the body weight of mice with Trypanosoma brucei bruceiinduced sleeping sickness was seen at 0, 12 and 19 days of the protocol (Figure 1). It was observed that the body weight of $T$. brucei brucei-infected mice was significantly $(p<0.05, p$ $<0.01$ ) decreased on the $12^{\text {th }}$ day (Without drug treatment) compared with the control group. This fall in the body weight continued in the negative control group up to the $19^{\text {th }}$ day of the protocol.

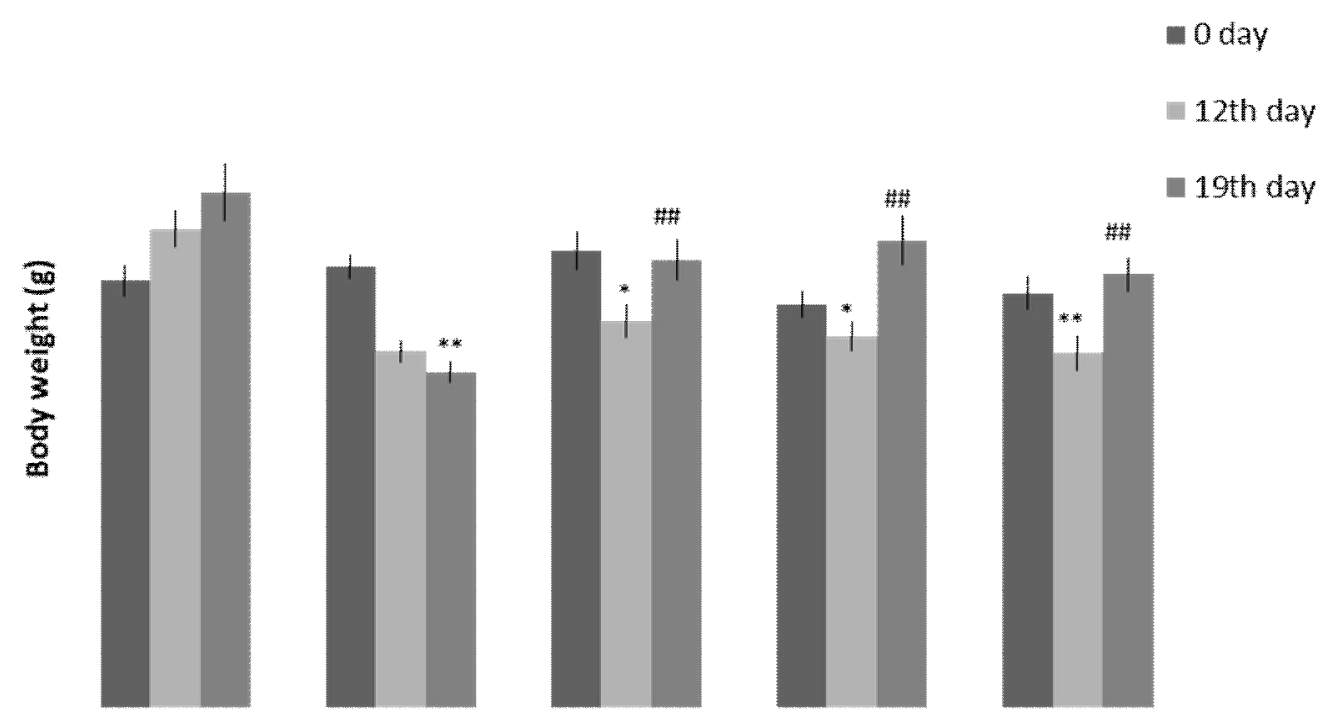

Figure 1: Effect of Malva sylvestris extracton body weight of sleeping sickness mice model. Values are mean \pm $\mathrm{SD} ;{ }^{*} p<0.05 ;{ }^{* *} p<0.01$ compared with control group; ${ }^{\#} p<0.01$ compared with negative control group 
However, treatment with MS and STD significantly $(p<0.01)$ improved the weight of Trypanosoma brucei brucei-induced sleeping sickness mice.

\section{Effect of Malva sylvestris extract on the parasite count}

The effect of MS on parasite count in the blood and CSF of the sleeping sickness mouse model is shown in Figure 2. There was an increase in the count of parasites in the blood and CSF of mice after the $12^{\text {th }}$ day of the protocol (i.e. period of induction of parasitaemia), confirming the induction of parasitaemia. However, treatment with MS and STD significantly $(p<0.01)$ decreased the count of parasites in the blood and CSF of the sleeping sickness mouse model compared with that of the negative control group.

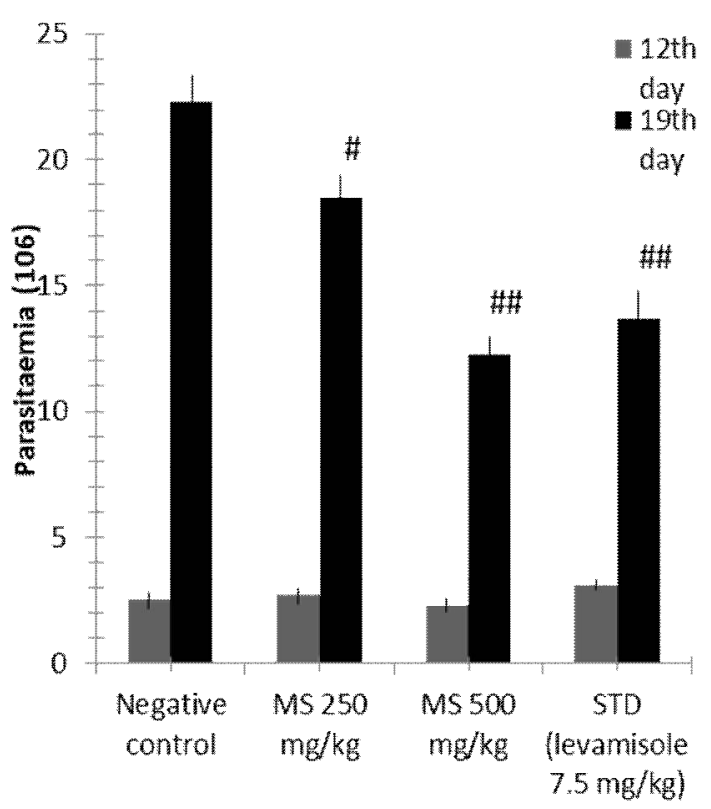

(A)

\section{Effect of Malva sylvestris extract on delayed hypersensitivity reaction}

The effect of Malva sylvestris on delayed hypersensitivity reaction in the sleeping sickness mouse model was estimated by determining the paw swelling (Table 1). It was observed that treatment with MS 250 and $500 \mathrm{mg} / \mathrm{kg}$ significantly reduced the paw swelling. Moreover, it also decreased the inhibition.

Effect of Malva sylvestris extract on the humoral antibody response

The effect of MS on the humoral antibody response is shown in Table 2. There was a significant increase in the SRBC secondary antibody production in the MS- and STD-treated groups compared with that in the control group. It was observed that the production of secondary antibody was enhanced in the MS-treated group in a dose-dependent manner.

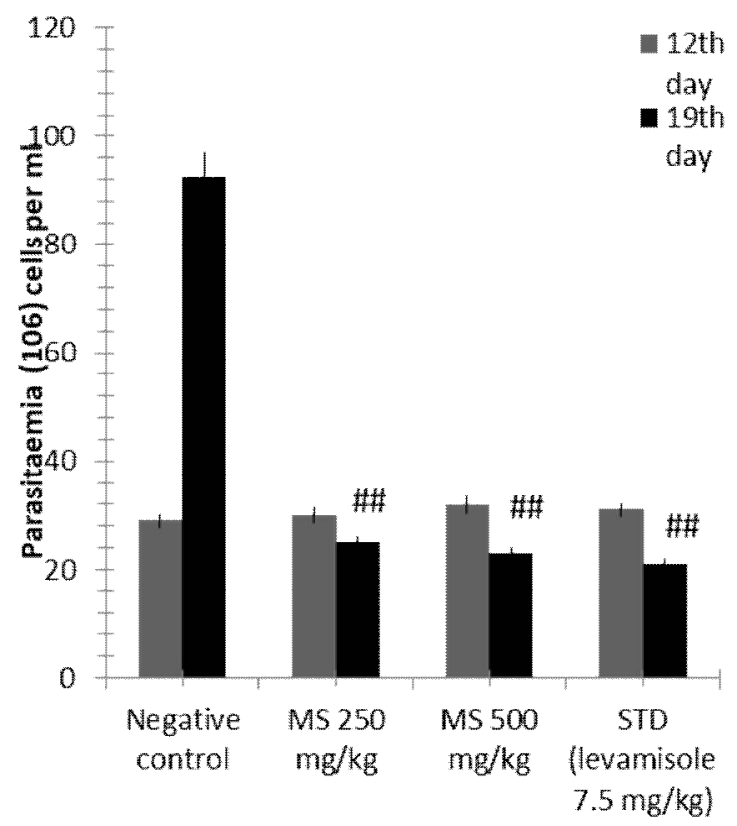

(B)

Figure 2: Effect of Malva sylvestris extract on the parasitaemia of sleeping sickness mice model (A) parasite count in blood (B) parasite count in CSF. Values are mean \pm SD; $p<0.05, " p<0.01$ compared with control group, ${ }^{\#} p<0.01$ compared with negative control group

Table 1: Effect of Malva sylvestris extract on delayed hypersensitivity reaction in sleeping sickness mice model

\begin{tabular}{lcc}
\hline Group & Paw swelling (mm) & Inhibition (\%) \\
\hline Control & $1.09 \pm 0.07$ & -- \\
MS $(250 \mathrm{mg} / \mathrm{kg})$ & $1.21 \pm 0.05^{\#}$ & $-17.52 \pm 1.9$ \\
MS $(500 \mathrm{mg} / \mathrm{kg})$ & $1.83 \pm 0.06^{\#}$ & $-23.86 \pm 2.2$ \\
Standard* & $1.08 \pm 0.09$ & 00.00 \\
\hline Note: Values are mean $\pm \mathrm{SD} ;{ }^{\#} p<0.05,{ }^{\# \#} p<0.01$ compared with control group; ${ }^{*}$ levamisole $7.5 \mathrm{mg} / \mathrm{kg}$
\end{tabular}


Table 2: Effect of Malva sylvestris on primary and secondary response $\left(\log _{10} 2\right)$ in sleeping sickness mice model

\begin{tabular}{lll}
\hline Group & $\begin{array}{l}\text { Primary antibody } \\
\left(\log _{10} 2\right)\end{array}$ & $\begin{array}{l}\text { Secondary antibody } \\
\left(\log _{10} 2\right)\end{array}$ \\
\hline Control & $1.32 \pm 0.37$ & $1.57 \pm 0.32$ \\
MS $(250 \mathrm{mg} / \mathrm{kg})$ & $3.53 \pm 0.05$ & $3.15 \pm 0.87^{\# \#}$ \\
MS $(500 \mathrm{mg} / \mathrm{kg})$ & $4.83 \pm 0.06$ & $8.52 \pm 1.31^{\# \#}$ \\
STD (levamisole $7.5 \mathrm{mg} / \mathrm{kg})$ & $2.95 \pm 0.69$ & $2.97 \pm 0.46^{\# \#}$ \\
\hline Note: Values are means \pm SD; ${ }^{\#} p<0.05,{ }^{\# \#} p<0.01$ compared with control group
\end{tabular}

Table 3: Effect of Malva sylvestris extract on the leucocytes mobilization in sleeping sickness mice model

\begin{tabular}{|c|c|c|c|c|c|c|}
\hline Group & $\begin{array}{l}\text { TLC } \\
\text { (cells/mL) }\end{array}$ & $\begin{array}{l}\text { Neutrophil } \\
\text { (cells/mL) }\end{array}$ & $\begin{array}{l}\text { Lymphocyte } \\
\text { (cells/mL) }\end{array}$ & $\begin{array}{l}\text { Basophil } \\
\text { (cells/mL) }\end{array}$ & $\begin{array}{l}\text { Monocyte } \\
\text { (cells } / \mathrm{mL} \text { ) }\end{array}$ & $\begin{array}{l}\text { Eosinophil } \\
\text { (cell/smL) }\end{array}$ \\
\hline $\begin{array}{l}\text { Control } \\
\text { MS }(250 \mathrm{mg} / \mathrm{kg})\end{array}$ & $\begin{array}{l}957 \pm 89 \\
1418 \pm 215^{\# \#}\end{array}$ & $\begin{array}{l}184 \pm 8.2 \\
259 \pm 11.5^{\# \#}\end{array}$ & $\begin{array}{l}742 \pm 52 \\
810 \pm 71^{\#}\end{array}$ & $\begin{array}{l}16.5 \pm 1.1 \\
1.2 \pm 0.15^{\# \#}\end{array}$ & $\begin{array}{l}17.9 \pm 1.2 \\
10.2 \pm 1.5^{\# \#}\end{array}$ & $\begin{array}{l}6.3 \pm 0.8 \\
4.1 \pm 0.3^{\# \#}\end{array}$ \\
\hline MS (500 mg/kg) & $1672 \pm 319^{\# \#}$ & $341 \pm 19.6^{\# \#}$ & $1085 \pm 85^{\# \#}$ & $00 \pm 00$ & $3.1 \pm 0.7^{\# \#}$ & $2.7 \pm 0.15^{\# \#}$ \\
\hline $\begin{array}{l}\text { STD } \\
\text { (levamisole } 7.5 \\
\mathrm{mg} / \mathrm{kg} \text { ) }\end{array}$ & $1130 \pm 140^{\# \#}$ & $277 \pm 17.3^{\# \#}$ & $879 \pm 48^{\# \#}$ & $1.6 \pm 0.3^{\# \#}$ & $1.6 \pm 0.5^{\# \#}$ & $00 \pm 00$ \\
\hline
\end{tabular}
Effect of Malva sylvestris extract on the
mobilization of leucocytes

The effect of MS on the mobilization of leucocytes is shown in Table 3. The mobilization of the total leucocyte (TLC), neutrophil and lymphocyte count was significantly enhanced in the MS-and STD-treated group compared with that in the control group. Moreover, the basophil, monocyte and eosinophil counts were decreased in the MS- and STD-treated groups compared with that in the control group of mice.

\section{DISCUSSION}

Protozoal infection of Trypanosoma brucei brucei causes epidemic encephalitis [13]. The literature suggested that infection of Trypanosoma brucei brucei caused fatal if it remains untreated [2]. However, effective management of sleeping sickness remains a challenge, and several molecules from herbal sources have demonstrated a therapeutic potential for the management of the disease $[14,15]$. Thus, this study evaluated the anti-trypanosomal effects of Malva sylvestris extract on a Trypanosoma brucei brucei-infected mouse model of sleeping sickness. The study also postulated the possible mechanism of its action.

In this study, MS treatment significantly led to the recovery of mice body weight of Trypanosoma brucei brucei-induced sleeping sickness compared with that in negative control group. The literature suggests that the enhanced parasite count confirms the induction of parasitaemia in all the Trypanosoma brucei brucei-induced sleeping sickness mice [16].
However, it also decreased the parasite count in the blood and CSF of Trypanosoma brucei brucei-induced sleeping sickness mice compared with that in negative control group.

Protection of the body from pathogens is the fundamental function of the immune system. Thus, the drugs that can stimulate the immune system are effectively used for the management of this disease [17]. In this study, the mechanism of anti-trypanosomal activity of MS is believed to be due to immunomodulatory activity. Infection of intracellular pathogens is majorly influenced by delayed hypersensitivity reaction. Delayed hypersensitivity represents cellular immunity that activates the production of cytokines, thereby deactivating the antigen [18]. However, treatment with MS significantly enhanced the paw swelling, indicating that the extract may have antiinflammatory properties. However, the results of the mobilization of leukocytes also suggest that MS significantly enhances TLC, neutrophil and lymphocyte counts in the blood. These results suggest that MS stimulates the immune system.

\section{CONCLUSION}

The results confirm the anti-trypanosomal activity of Malva sylvestris extract by immunomodulation. The extract of Malva sylvestris has potentials for the management of sleeping sickness.

\section{DECLARATIONS}

\section{Acknowledgement}

The authors would like to thank the Department 
of Neurology, Hubei Provincial Hospital of TCM, China for providing the facilities for this work.

\section{Conflict of Interest}

No conflict of interest associated with this work.

\section{Contribution of Authors}

The authors declare that this work was done by the authors named in this article and all liabilities pertaining to claims relating to the content of this article will be borne by them.

\section{Open Access}

This is an Open Access article that uses a funding model which does not charge readers or their institutions for access and distributed under the terms of the Creative Commons Attribution License (http://creativecommons.org/licenses/by/ 4.0) and the Budapest Open Access Initiative (http://www.budapestopenaccessinitiative.org/rea d), which permit unrestricted use, distribution, and reproduction in any medium, provided the original work is properly credited.

\section{REFERENCES}

1. Pascal G, Paul C, Jean-Paul B, Edith D, Géraldine $S$, Patrick J, Vincendeau P, Zakaria B, Alain B, Gérard C, et al. Identification of total and differentially expressed excreted-secreted proteins from Trypanosoma congolense strains exhibiting different virulence and pathogenicity. Int J Parasitol 2009; 39: 1137-1150.

2. Lima FM, Oliveira $P$, Mortara RA, Silveira JF, Bahia D. The challenge of Chagas' disease: has the human pathogen, Trypanosome cruzi, learned how to modulate signaling events to subvert host cells? J New Biotechnol 2010; 27: 837-844.

3. Nweze NE, Fakae LB, Asuzu IU. Trypanocidal activity of the ethanolic extract of Buchholzia coriacea seed. Nig Vet $J$ 2009; 29: 1-6.

4. Blum J, Schmid C, and Burri C. Clinical aspects of 2541 patients with second stage human African trypanosomiasis. Acta Tropica 2006; 97: 55-64.

5. Bisser S, Ouwe-Missi-Oukem-Boyer ON. Toure F. S. Harbouring in the brain: a focus on immune evasion mechanisms and their deleterious effects in malaria and human African trypanosomiasis. Int $J$ Parasitol 2006; 36 : 529-540.
6. Kumar SV, Kumar SP, Rupesh D, Kumar $N$. Immunomodulatory effects of some traditional medicinal plants. J Chem Pharm Res 2011; 3: 675-684.

7. Prudente AS, Loddi AM, Duarte MR, Santos AR, Pochapski MT, Pizzolatti MG, Hayashi SS, Campos FR, Pontarolo R, Santos FA, Cabrini DA, Otuki MF. Preclinical anti-inflammatory aspects of a cuisine and medicinal millennial herb: Malva sylvestris L. Food Chem Toxicol 2013; 58: 324-331.

8. Cheng C, Wang ZY. Bacteriostasic activity of anthocyanin of Malva sylvestris. J Forestry Res 2006; 17: 83-85.

9. Patricia FE, Sato A, Esquibel MA, Campos-buzz F, Meria AV, Cechinel-Filho V. Antinociceptive Activity of Malva sylvestris L. Lat Am J Pharm 2009; 28 (3): 454-456.

10. Wang C, Pei A, Chen J, Yu H, Sun ML, Liu CF, Xu X. A natural coumarin derivative esculetin offers neuroprotection on cerebral ischemia/reperfusion injury in mice. J Neurochem 2012; 121(6):1007-1013.

11. Min J, Yu SW, Baek SH, Nair KM, Bae ON, Bhatt A, Kassab M, Nair MG, Majid A. Neuroprotective effect of cyanidin-3-O-glucoside anthocyanin in mice with focal cerebral ischemia. Neurosci Lett 2011; 500(3):157-161.

12. Guide for the Care and Use of Laboratory Animals: Eighth Edition Committee for the Update of the Guide for the Care and Use of Laboratory Animals; National Research Council. 2010; ISBN: 0-309-15401-4.

13. Dumas $M$, Bouteille $B$, Buguet $A$, Eds. Progress in human African trypanosomiasis, sleeping sickness. Paris: Springer-Verlag; 1999.

14. Tagboto S, Townson S. Antiparasitic properties of medicinal plants and other naturally occurring products. Adv Parasitol 2001; 50: 199- 295.

15. Peter O, Magiri E, Auma J, Magoma G, Imbuga M and Murilla $G$. Evaluation of in vivo antitrypanosomal activity of selected medicinal plant extracts. J Medicin Plant Res 2009; 3(11): 849-854.

16. Louis FJ, Kohagne $L T$, Ebo'O EV, Simarro PP. Organizing an active screening campaign for human African trypanosomiasis due to Trypanosoma brucei gambiense. Medecin Tropic 2008; 68: 11-16.

17. Singhal M, Ratra P. Investigation of immunomodulatory potential of methanol and hexane extract of Musa acuminate peel (Plantain) extracts. Global J Pharmacol 2013; 7: 69-74.

18. Eze Jl, Ekelozie CF, Nweze NE. Immunomodulatory activity of Buchholzia coriacea seed methanol extract on Trypanosoma brucei brucei infected mice. Pharmaceut Biol 2017; 55: 636-640 